\title{
Iringan Musik Dalam Pantomim
}

\author{
Nur Iswantara ${ }^{1}$
}

\begin{abstract}
Pantomime is one of the oldest theater arts, where mime artists tell something just using their body, without talking. Pantomime artists are known for their white makeup and black pigtails, as well as other facial features to exaggerate their emotions. Black and white striped tops, white gloves and black hats are also complete with traditional Pantomime artist costumes. These clothes and makeup have become a tradition of many Pantomime artists. In adding the atmosphere of the movement displayed, a music illustration is given to bring the atmosphere to life.

This study uses qualitative methods and action research methods which is a reflective research method. This type of research is able to offer new ways and procedures to improve and enhance the professionalism of pantomime presentation techniques. The approach used is structural and educative. The structure approach is used to solve something related to the arrangement or building of multi-level pantomime presentations, while the educational approach is used to solve those relating to pantomime education.

Music illustrations in the Pantomime show can support the atmosphere of the show. The music played can be adjusted to the theme of the movement played by a Pantomime.
\end{abstract}

Keywords: Pantomime, Illustration of Music, Atmosphere.

\begin{abstract}
Abstrak
Pantomim adalah salah satu kesenian teater yang paling tua, di mana seniman pantomim menceritakan sesuatu hanya menggunakan tubuhnya, tanpa berbicara. Seniman Pantomim terkenal dengan riasan putih dan celak hitam, serta tampilan wajah lain untuk melebih-lebihkan emosinya. Atasan bergaris hitam putih, sarung tangan putih dan topi hitam juga adalah kelengkapan kostum seniman Pantomim tradisi. Pakaian dan riasan ini telah menjadi tradisi dari banyak seniman Pantomim. Dalam menambahkan suasana dari gerakan yang ditampilkan, maka diberikan sebuah ilustrasi musik untuk menghidupkan suasananya.

Penelitian ini memakai metode kualitatif dan metode penelitian tindakan yaitu suatu metode penelitian reflektif. Jenis penelitian ini mampu menawarkan cara dan prosedur baru untuk memperbaiki dan meningkatkan profesionalisme teknik penyajian pantomim. Pendekatan

\footnotetext{
${ }^{1}$ Dosen jurusan Sendratasik FSP ISI Yogyakarta.
} 
yang digunakan adalah struktur dan edukatif. Pendekatan struktur digunakan untuk memecahkan sesuatu yang berkaitan dengan susunan atau bangunan penyajian pantomim multi level, sedangkan pendekatan edukatif digunakan untuk memecahkan yang berkaitan dengan pendidikan pantomim.

Ilustrasi musik dalam pertunjukan Pantomim dapat mendukung suasana pertunjukan itu. Musik yang dimainkan dapat disesuaikan dengan tema dari gerakan yang dimainkan oleh seorang Pantomim.

Kata Kunci: Pantomim, Ilustrasi Musik, Suasana.

\section{Pendahuluan}

Selama ini pantomim diajarkan di sekolah-sekolah sebagai kegiatan ekstra kurikuler yang dikaitkan dengan seni drama/teater. Bahkan seni pantomim tidak diajarkan sama sekali, karena kurangnya sumber daya manusia dan apresiasi terhadap seni pantomim di Indonesia.

Pantomim merupakan aset budaya bangsa Indonesia, berupa produk karya seni individu dan kolektif yang memiliki kandungan nilai seni (estetika), rekreasi (kegiatan tontonan dan hiburan), promosi (kegiatan propaganda dan penerangan), ekonomi (kegiatan pencaharian), dan edukasi (kegiatan pendidikan). Nilai seni (estetika) nampak dalam gerak-gerik aktor/seniman pantomim yang berekspresi melalui bahasa isyarat dengan tubuhnya. Nilai rekerasi atau hiburan dapat dipresentasikan dengan kreasi-kreasi yang bersifat menghibur (menyenangkan), rasa nikmat dan rasa humor (membuat ketawa). Nilai promosi terungkap dalam ajakan atau tawaran terhadap produk-produk bangsa Indoensia yang bersifat moral dan material untuk dijadikan konsumen bagi penonton. Nilai ekonomi dapat dikemas sebagai media pergerakan ekonomi bagi pelaku seni pantomim (seniman), produksi dan penerbitan. Nilai pendidikan (edukasi) terungkap dalam pengajaran moral/watak/sifat/budi pekerti melalui cerita, tokoh, dan perilaku visual para seniman di area pertunjukan. Dengan Pantomim inilah mahasiswa dan masyarakat diharapkan mendapatkan apresiasi dan nilai-nilai pendidikan karakter.

Sayang sekali seni pantomim yang begitu komprehenship dalam makna dan fungsi tersebut kurang mendapatkan perhatian di kalangan generasi penerus yang berada dalam lingkup pendidikan (perguruan tinggi) secara nasional. Hal itu 
dapat dipahami karena pantomim masih dalam format satu level yang orientasinya pada hayatan senimannya. Hal inilah yang menjadikan pantomim belum bisa menyentuh dunia pendidikan di Indonesia yang bersifat khusus dan berskala nasional. Di sisi lain, bangsa Indonesia sekarang ini mengalami dismoral, karena kehilangan jati diri yang bersumber pada nilai-nilai 'Kebinekaan' (beragaman suku, agama, budaya, pendidikan, usia, kelamin, dan sebagainya) yang memuncak pada semboyan 'Tunggal Ika' (menjadi satu tujuan, satu cita-cita, dan satu bangsa untuk bersatu padu).

Untuk itu, maka perlu diciptakan model metode pantomim dalam perspektif pendidikan tersendiri yang dapat dijadikan sebagai materi pendidikan karakter bagi anak bangsa Indonesia yang berbasis pada budaya sendiri. Pada kesempatan ini lebih fokus dalam bentuk kemasan metode pantomim yang dikaitkan dengan iringan musiknya.

Pantomim yang ada sekarang ini masih bersifat mono level, berorientasi pada hayatan senimannya dan fantasi orang dewasa yang mengutamakan nilai seni sehingga sulit diterima oleh lembaga pendidikan di Indonesia yang multi level (PAUD, SD, SMP, SMA, PT) dan multi etnis (Jawa, Sumatera, Kalimantan, Sulawesi, Bali, Madura, dan Papua). Penciptaan metode pantomim ini dapat diterapkan pada lembaga pendidikan nasional di negara kita Indonesia, dan berdampak pada peningkatan nilai edukasi dan menjunjung tinggi nilai-nilai kesatuan dan persatuan di dalam hidup bernegara dan berbangsa (pendidikan karakter/budi pekerti) melalui kajian budaya Indonesia yaitu Pantomim. Oleh karena diterapkan pada dunia pendidikan formal, maka format pantomim diajarkan secara kognitif (pengetahuan/mengetahui), afektif (memahami/merasakan), dan psikomotorik (mampu melakukan/trampil).

Secara khusus penelitian ini bertujuan ingin mengembangkan seni Pantomim yang memiliki nilai edukatif dalam rangka ikut serta membangun moral bangsa Indonesia yang sedang dirundung disbudaya dan dismoral. Dengan pantomim multi level dan multi etnis bangsa Indonesia dapat memahami nilainilai kebinnekaan dan ketunggalikaan yang merupakan ideologi bangsa Indonesia. 
Pendidikan Pantomim multi level diharapkan dapat diajarkan secara nasional pada lembaga-lembaga pendidikan negeri maupun swasta mulai dari PAUD, SD, SMP, SMA, PT sehingga nilai-nilai pedidikan melalui seni pantomim dapat diapresiasi oleh masyarakat di lingkungan lembaga pendidikan tingkat awal sampai akhir.

Pendidikan Pantomim multi etnis dan nasionalis dapat dijadikan sebagai media apresiasi keberagaman dan kesatuan melalui seni budaya produk anak bangsa sendiri. Dengan Pantomim dalam perspektif pendidikan inilah bangsa Indoensia dapat bersatu walaupun berbeda level dan etnisnya. Produk seni milik bangsa sendiri lebih mampu untuk mewujudkan cita-cita bangsa, karena sesuai dengan ideologinya.

Penelitian ini penting untuk dilakukan, dalam rangka mengatasi permasalahan menurunnya apresiasi masyarakat terhadap seni pantomim sebagai karya budaya bangsa sendiri dan merosotnya aklak bangsa Indonesia. Kurangnya apresiasi seni pantomim dan nilai pendidikan untuk mengembangkan budaya sendiri sesuai perkembangan zaman ini mendesak dilakukan penelitian untuk menghasilkan produk terapan metode pantomim di Indonesia dalam perspektif pendidikan.

Masalah pertama adalah masalah apresiasi seni pantomim yang menurun dan bersifat mono level, yakni lebih berorientasi senimannya atau seni orang dewasa sehingga kurang disosialisasikan ke dalam sistem pendidikan multi level. Masalah kedua merosotnya akhlak anak bangsa Indonesia akibat perkembagan zaman. Ketidaksesuaian ini yang menimbulkan disapresiasi, karena merasa bukan dirinya atau bukan lingkungannya. Dengan munculnya kedua masalah tersebut perlu diatasi dengan menciptakan Pantomim dari sebuah perspektif pendidikan yang menggabungkan antara Pantomim dan musik iringannya supaya semua lembaga pendidikan di Indonesia dapat mengapresiasi dan melaksanakan ajaran moral yang terkandung melalui seni Pantomim. 


\section{Iringan Musik Dalam Pantomim}

Musik dapat membangkitkan sebuah suasana atau roh yang diinginkan oleh seorang komposernya. Suatu komposisi musik berkaitan dengan kemampuan seorang composer dalam mengolah suatu bentuk musik yang dimainkan. Musik memiliki karakter yang berkaitan dengan suasana manusia dan kehidupan seperti sedih, senang, riang, gembira, berduka, dan lain-lain. Keseluruhan hal tersebut dapat diwujudkan dalam sajian musik.

Suatu bentuk music yang dipergunakan dalam pertunjukan Pantomim didekatkan dari suasana yang diciptakan oleh pemainnya sesuai tema gerakan tersebut. Pantomim adalah salah satu kesenian teater yang paling tua, di mana seniman pantomim menceritakan sesuatu hanya menggunakan tubuhnya, tanpa berbicara. Walaupun sering kali digunakan sebagai lelucon, pantomim sebenarnya adalah aktivitas yang ceria dan menyenangkan baik untuk aktor serius atau pun orang-orang yang ingin bersenang-senang bersama temannya. Seniman Pantomim harus memiliki tubuh seperti pesenam, pikiran seperti aktor, dan hati seorang pujangga. Banyak orang yang pernah menjalani latihan Pantomim saat ini dikenal sebagai "teater fisik" untuk menghindari stigma sosial yang sering dikaitkan dengan Pantomim. Sebagian seniman tidak lagi menggunakan riasan tradisi Pantomim. Seniman Pantomim terkenal dengan riasan putih dan celak hitam, serta tampilan wajah lain untuk melebih-lebihkan emosinya. Atasan bergaris hitam putih, sarung tangan putih dan topi hitam juga adalah kelengkapan kostum seniman Pantomim tradisi. Pakaian dan riasan ini telah menjadi tradisi dari banyak seniman Pantomim terkenal termasuk juga legenda Pantomim Marcel Marceau.

Adapun unsur-unsur pembentuk sebuah cerita dalam Pantomim yaitu:

1. Mimik: Seorang pemain pantomim sangat mengandalkan ekspresi mimik dalam menerangkan suatu keadaan seperti sedih, marah, kecewa, gembira, bingung, dan lain-lin.

2. Gerak: Gerak tubuh bertugas menciptakan sesuatu yang tidak ada menjadi ada, seperti memegang gelas, memegang pisau, memegang kaca, berjalan, berlari, naik tangga, dan lain-lin. 
Musik dalam hal ini sangat mendukung guna menciptakan suasana atau atmosfer situasi yang terjadi sehingga penonton juga dapat larut dalam situasi itu seperti situasi seram, situasi bahagia, situasi sedih, dan lain-lin. Sesuatu hal yang berkaitan dengan musik, maka seorang pemain pantomim juga harus mampu menguasai tempo dalam sebuah irama sehingga ia dapat menyesuaikan gerak tubuhnya dengan tempo lagu/irama yang saat itu terdengar. Hal ini sangat penting agar penonton tidak merasakan kejanggalan karena apa yang dilihat tidak sesuai dengan apa yang didengar. Contohnya, musik dalam keadaan sedih mungkin dipilih yang temponya pelan, dalam keadaan tergesagesa mungkin temponya cepat, dan lain-lin.

Langkah-langkah yang ditempuh dalam pembelajaran dan pelatihan Pantomim sebagai berikut:

a. Pemanasan dan Pelemasan dilakukan dengan cara:

1. Berlari-lari kecil di tempat

2. Menggerakkan kepala:

- Menekan kepala ke depan dan ke belakang

- Menekan kepala ke kiri dan ke kanan

- Menoleh ke kiri dan ke kanan

- Memutar kepala dan diulangi dengan arah sebaliknya

3. Menggerakkan bahu

- Menggerakkan bahu ke atas dan ke bawah

- Menggerakkan bahu ke depan dan ke belakang

- Memutar bahu

4. Menggerakkan tangan hingga jari jemari

- Menggerakkan pergelangan tangan

- Menggerakkan jari jemari

5. Menggerakkan pinggul

- Menggerakkan ke kiri dan ke kanan

- Menggerakkan ke depan dan ke belakang

- Memutar pinggul

6. Menggerakkan lutut 
- Menggerakkan ke kiri dan ke kanan

- Menggerakkan ke depan dan ke belakang

- Memutar lutut

7. Senam Wajah

- Menggerakkan alis mata

- Menggerakkan pelupuk mata

- Menggerakkan kening

- Menggerakkan mulut

- Menggerakkan pipi

8.Kembali berlari-lari kecil di tempat sambil bertepuk tangan

9. Menghela napas

b. Imajinasi Benda

1. Membayangkan penggunaan benda-benda di sekitar, seperti gelas, kursi, kayu, batu, dan lain-lain

2. Menggunakan benda-benda itu dengan menyesuaikan bentuk dan berat benda serta penggunaannya dalam kehidupan sehari-hari

3. Menyadari kadar tekanan, bawaan maupun interaksi benda dengan tubuh. Misalnya: interaksi bola yang melambung berbeda dengan tali yang ditarik c. Eksplorasi Emosi dan Perilaku

1. Menentukan berbagai bentuk emosi: marah, menangis, tertawa, ngambek, terkejut, takut, ngeri dan sedih

2. Memberikan arahan tentang peristiwa emosi yang akan dilakukan

3. Melakukan dan membentuk perilaku emosi secara bergantian

4. Mempertemukan (berpasangan) bentuk-bentuk emosi

5. Mencipta Bentuk

d. Bentuk dasar (perhatikan pergerakan tubuh)

1. Berjalan

2. Memegang benda

3. Mengangkat benda

4. Menarik benda

5. Menekan sesuatu (bisa dinding, tubuh temannya dan benda lainnya) 
6. Melempar

e. Bentuk imajinatif

1. Berjalan sambil melambaikan tangan

2. sambil membayangkan benda-benda, seperti gelas, tas, bola

3. Mengangkat sesuatu yang ada dalam bayangan anak-anak

4. Menarikdan saling menarik satu sama lainnya

5. Menekan maupun bersandar pada suatu objek

6. Melempar sesuatu ke arah yang diinginkan

f. Membuat Cerita/Narasi

1. Narasi dapat berupa cerita sehari-hari maupun dari legenda

2. Narasi dibuat sederhana dengan tokoh-tokoh/peran yang sederhana.

Misalnya, Kancil yang licik, Anak yang rajin

3. Mulailah dengan sebuah cerita agar anak-anak dapat membangun imajinasi peristiwa maupun dapat mengembangkan dan menyesuaikannya dengan pengalaman yang ditransformasikannya.

g. Make-up dan Kostum

1. Make-up dan kostum berguna untuk mempertegas peran yang dimainkan

2. Make-up dan kostum akan lebih baik jika mampu mendorong gerak yang sesuai dengan peran

3. Kemampuan melakukan peran-peran tertentu dapat mengubah make-up dan kostum menjadi bagian yang sekunder.

h. Memulai dengan Keyakinan

Pertanyaan yang sering muncul ketika memulai sesuatu adalah bagaimana cara memulainya. Dalam proses kreatif, dikenal adanya motif. Motif akan menjadi titik tolak seseorang untuk memulai suatu proses. Motif merupakan titik sasaran seseorang dalam bertindak. Maka, mulailah dengan menentukan motif Anda memulai sesuatu. Misalnya motif memberdayakan anak didik, memberdayakan diri sendiri, pergaulan, menumbuhkan rasa ingin tahu, ingin belajar dan sebagainya. Motif-motif ini akan menentukan tindakan seseorang dalam proses kreatif. Semakin baik motif yang dipilih, maka semakin tinggi pula upaya yang dilakukan dan semakin baik pencapaian dari motif tersebut. 
Motif yang dimiliki, selanjutnya diikuti dengan niat dan kemauan untuk menjalankannya sebaik mungkin.

Dalam melakukan Pantomim gunakan tubuh untuk berbicara. Ketika Pantomim, berbicara atau mengucapkan kata-kata tidak diperlukan. Sebaliknya, gunakan ekspresi wajah dan memanfaatkan seluruh tubuh untuk melakukan hal yang 'berbicara'. Gunakan cermin (atau penonton) untuk menilai gerakan apa yang paling berhasil dalam menyampaikan emosi, perasaan, sikap dan reaksi. Sebuah cermin panjang penuh merupakan suatu keharusan untuk pemula tapi ingat cermin adalah teman dan akan perlu untuk meninggalkan pada waktu kinerja. Sebuah kamera video, jika tersedia, juga merupakan alat yang sangat berharga untuk dimanfaatkan.

Mulailah dengan tindakan dasar Pantomim. Ada beberapa teknik yang cukup standar yang kebanyakan para seniman pantomim mulai. Ini termasuk kerja imajiner memanipulasi obyek (seperti dinding, bola, tali, dan sebagainya), berjalan di tempat, memanjat tangga imajiner, bersandar, dan sebagainya.

Menggunakan imajinasi tidak dapat terlalu menekankan dalam menciptakan ilusi. Paling penting adalah untuk mime untuk benar-benar percaya bahwa ilusi adalah nyata. Tentu lebih nyata ilusi adalah untuk mime, yang lebih realistis itu akan menjadi sesuatu bagian dari audiens. Hal ini dapat dicapai melalui praktek. Praktek semua ilusi dalam cara yang sama, misalnya (dalam berlatih dinding), mengimajinasikan dinding yang nyata. Lihat dinding dalam warna berbeda. Rasakan dinding tekstur yang berbeda yaitu merasakannya kasar, halus, basah, kering, dingin atau panas. Gunakan teknik-teknik yang sama saat berlatih semua ilusi. Selain itu juga akan menemukan tubuh bereaksi secara alami pada ilusi jika yakin itu asli. Pertimbangkan apa yang mungkin dilakukan dan bagaimana bereaksi jika berinteraksi dengan hal yang nyata.

Berpura-pura memiliki tali gantung sebelum mencoba untuk mendaki itu. Geser ke bawah dan memanjat kembali ke atas untuk efek terbaik. Ketika mencapai puncak, menghapus keringat di dahi. Pendakian tali adalah ilusi yang sangat sulit jika dilakukan dengan benar. Bayangkan dan rasakan berat badan, jika benar-benar memanjat tali, otot-otot akan meregangkan dan ketegangan. Wajah 
akan meringis dalam upaya menyakitkan. Menyeka keringat dari kening akan menjadi reaksi alamiah. Apabila belum pernah memanjat tali yang nyata, melakukannya dengan pengawasan dalam olah raga empuk. Membuat catatan mental tindakan dan reaksi meskipun banyak ilusi mungkin tidak dilakukan dengan gerakan yang tepat seperti yang digunakan dalam kenyataannya, sikap mental (alias imajinasi) harus sama sebagai hal yang nyata. Untuk menampilkan memanjat tangga, ambil di anak tangga imajiner naik di udara. Tempatkan bola dari satu kaki di tanah. Meniti pada anak tangga (menjaga tangan bergerak bersama-sama). Saat pergi di jari-jari kaki, dan kemudian turun kembali dengan kaki yang berlawanan sekarang "pada anak tangga." Alternatif kaki dan tangan setiap kali "naik." Jaga fokus ke atas, seolah-olah sedang melihat tempat yang didaki. Membuat kaki melakukan gerakan yang sama seperti jika kaki kamu memanjat sebuah tangga yang nyata.

Berpura-pura dalam sebuah kotak. Jika berada dalam kotak tak terlihat, dapat menekan udara di depan dengan tangan, pertama telapak tangan dan kemudian jari-jari. Apabila mencoba untuk mencari jalan keluar dari kotak tak terlihat dengan mengidentifikasi sudut dan sisi, maka jalankan satu tangan di "pinggiran" kotak imajiner, seakan-akan mencoba untuk menemukan tutup dan jalan keluar. Jika dapat akhirnya menemukan tutup dan kotak terbuka secara dramatis dengan kedua tangan, dalam gerakan kemenangan.

Suasana yang ditampilkan oleh seorang Pantomim dapat direspon oleh seorang pemusik dalam mendukung suasana sesuai dengan tema ceritanya. Seseorang pemusik yang dapat menghayati dari tema dan gerakan yang disajikan oleh seorang Pantomim dapat menghidupkan suasana pertunjukannya. Karakter dari alat music yang dipergunakan dalam komposisinya disesuaikan dengan gerakan Pantomim itu sendiri.

\section{Kesimpulan}

Berdasarkan data dan pembahasan tersebut di atas, dapat disimpulkan bahwa pantomim di Indonesia dalam konteks pendidikan nasional dapat dibuat/dirancang metode pembelajarannya dalam rangka mendukung program 
pendidikan karakter/budi pekerti yang diagendakan oleh pemerintah melalui jalur pendidikan formal dan non formal. Dengan demikian metode pembelajaran pantomim perlu dikemas sesuai dengan tingkat perkembangan jiwa dan fisik peserta didik di berbagai level pendidikan. Hubungan Pantomim dengan music sangat berkesinmabungan dalam membangkitkan suasana yang diinginkan sehingga penontonnya dapat memahami dari gerakan yang dimainkan oleh seorang Pantomim.

Pantomim dalam presentasinya dengan bahasa isyarat melalui ekapresi wajah dan tubuh pelakunya dapat diapresiasi oleh setiap orang, keluarga, masyarakat dan warga bangsa Indonesia. Sisi lain Pantomim masih perlu dihidupi oleh seniman dan didukung masyarakat dalam hal ini diuji cobakan di masyarakat umum.

Meskipun ada banyak 'trik' yang membentuk dasar dari pelatihan pantomim, ada 'blok bangunan' yang mendasari beberapa yang membentuk teknik yang titk tetap (menjadi tumpuannya). Hal ini disebut sebagai 'fixe pointe', Bagaimanapun itu adalah sekedar kata-kata Perancis asli dari 'titik tetap'. Ini adalah ide yang sangat sederhana yang menempatkan mime titik dengan tubuhnya, dan kemudian menyimpannya bergerak dalam ruang. Teknik ini adalah dasar dari semua ilusi pantomim untuk dapat menciptakan diantaranya garis (line) yang dibangun berdasarkan titik tetap. Pada awalnya, dengan hanya menambahkan sebuah titik tetap kedua di ruang angkasa. Hal itu membuat keterampilan teknis ini menjadi unik karena kesulitan dengan ditambahkan sesuatu untuk menjaga dua poin jarak yang relatif sama dari satu sama lain. Juga, jarak relatif antara dua titik menjadi definisi dari 'blok konstruksi'. Dengan demikian, garis dapat menjadi 'tidak tetap' selama dua titik disimpan stabil dalam hubungan mereka satu sama lain. Sebuah aplikasi yang baik dari konsep ini adalah 'dinding mime'.

Banyak mime terlatih individu sekarang beroperasi di bawah 'teater fisik' istilah untuk menghindari stigma sosial yang sering mengilhami mime hari ini. Sebagian besar seniman tidak menggunakan kostum pantomim tradisional atau make-up. Khas hitam dan putih mime seniman make-up seniman terkenal untuk 
menggunakan wajah putih kosong make-up dengan warna hitam menguraikan mata dan fitur wajah lain untuk membesar-besarkan emosi. Sebuah atas bergaris hitam dan putih, sarung tangan putih dan topi hitam atas juga fitur dari sebuah kostum tradisional seniman pantomim. Ini pakaian dan make-up telah menjadi tradisi dari banyak seniman pantomim terkenal, termasuk Marcel Marceau legendaris.

\section{Daftar Pustaka}

Aubert., Charles. 1970. The Art of Pantomim, New York: Benjamin,Inc.

Harymawan, RMA. 1993. Dramaturgi,Bandung:Remaja Rosda Karya.

Hamzah, A.Adjib. 1985. Pengantar Bermain Drama, Bandung: Rosda Karya.

Iswantara, Nur. 1995. Kehidupan Seni Pertunjukan Pantomim di Yogyakarta, Yogyakarta: Laporan Penelitian Mandiri, Lembaga Penelitian Institut Seni Indonesia Yogyakarta.

1998. Pantomim di Indonesia Seni Pertunjukan Yang Tumbuh Ekspresif, Yogyakarta:Laporan Penelitian Pribadi, Yogyakarta: Teater Pelopor Yogyakarta.

1999. Gerak Pantomim, Gerak Perkembangan: Dilihat Dari Dua Kota Indonesia,Bandung:Laporan Penelitian Mandiri, Program Ekologi Teater Indonesia (PETI) Masyarakat Seni Pertunjukan Indonesia (MSPI) Bandung.

. 2007. Wajah Pantomim Indonesia Dari Sena Didi Mime Hingga Gabungan Aktor Pantomim Yogyakarta, Yogyakarta: Media Kreatifa.

Levin, Richard. 1960. Tragedy: Plays, Theory, and Criticism, New York: Harcourt Brace Javanovich,Inc.

Martin, Ben. 1978. Marcel Marceau Master of Mime, New York: Panddington Press.Ltd.

Pmd., Pramana. 29 Maret 1987. “Pantomim di Negeri ini”.Jakarta: SKH. Kompas.

Rendra, 1984. Mempertimbangkan Tradisi, Jakarta: PT. Gramedia.

Setyani Hartono, Bekti. 2006. "Teater Pantomim Kaki Kaki Tangan Kelompok Sena Didi Mime Pimpinan Didi Petet”, Skripsi Program Studi S-1 Seni 
Teater Yogyakarta: Fakultas Seni Pertunjukan Institut Seni Indonesia Yogyakarta (Tidak Diterbitkan).

Sumanto, Bakdi. 4 Nopember 1992. (FS-UGM), Pantomim dan kita, Makalah Diskusi Kehidupan Pantomim di Yogyakarta.

Suroso. 2009. Penelitian Tindakan Kelas. Yogyakarta: Pararaton.

Suryabrata, Sumadi. 2004. Psikologi Pendidikan. Jakarta: PT. Raja Grafindo Persada.

Tranggona, Indra. 1995. Gali Budaya Sendiri, Buku Panduan FKY ke-VII, Yogyakarta. 